\title{
Global Legal Pluralism and Conflict of Laws
}

\author{
Ralf Michaels
}

Global legal pluralism makes three claims about law:

1) law includes both state law and non-state law;

2) there is a plurality of laws;

3) laws overlap and interact in certain ways.

Among these, the third one is the most difficult one and at the same time the one least theorized. Pluralists lack the instruments to deal with them. The main reason is that they, with rare exceptions, ignore conflict of laws as the discipline that deals with such overlaps and interactions. As a consequence, discussions have stalled: Global legal pluralism is widely accepted as a helpful description of law in the world, but because a more precise conceptualization and theorization is lacking, that description has little impact for further analysis.

This chapter, forthcoming in the Oxford Handbook of Global Legal Pluralism, introduces conflict of laws as a technique and as a discipline to scholars of global pluralists. And it makes the case for why conflict of laws is the adequate discipline, doctrinally and epistemologically, to deal with overlaps and interactions of laws in Global Legal Pluralism. Conflict of laws is superior to other techniques of dealing with diversity due to its experience. Moreover, it is superior to other epistemologies due to a number of its characteristics, in particular its decentralized nature, its technical character, and its ethical position. Scholars working in global legal pluralism would do well to engage with it in a more comprehensive fashion.

I. THEME . .2

II. THREE TYPES OF RESPONSES TO PLURALITY. . .3

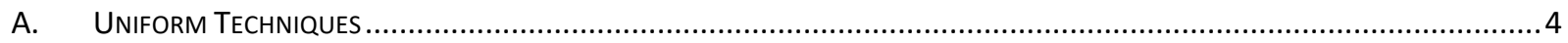

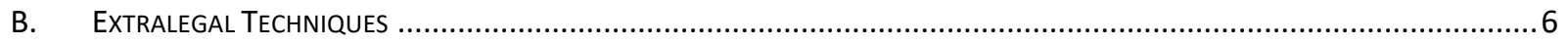

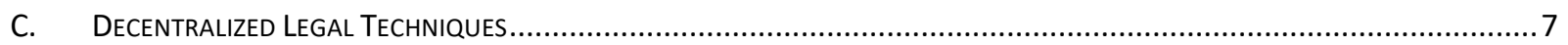

III. CONFLICT OF LAWS AS TECHNIQUE FOR PLURALITY.................................................................................

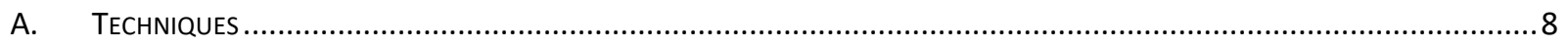

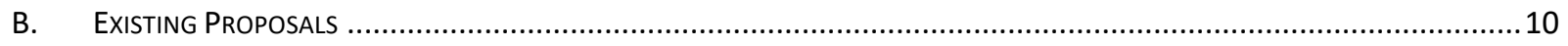

IV. THE FOURFOLD ADVANTAGE OF PRIVATE INTERNATIONAL LAW ..........................................................

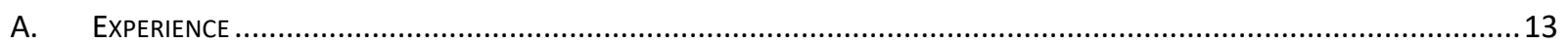

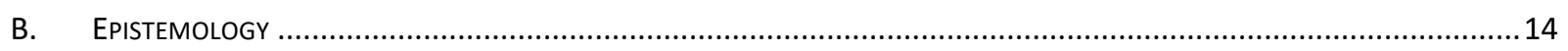

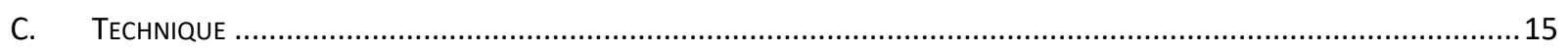

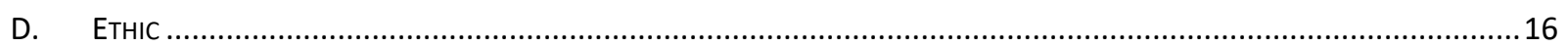

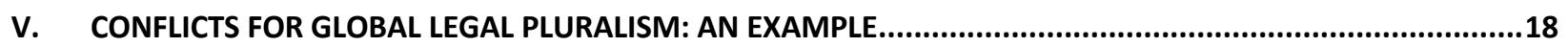

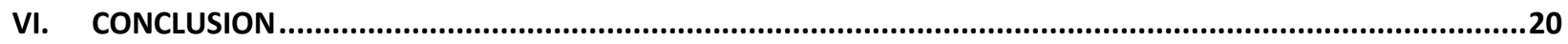




\section{Theme}

Global legal pluralism makes three claims about law:

1) law includes both state law and non-state law;

2) there is a plurality of laws;

3) laws overlap and interact in certain ways.

The first and the second of these claims go against what can be called methodological nationalism: conceiving of law exclusively within a state paradigm. They are important insofar as they go against this paradigm that has shaped legal thinking in the West since the nineteenth century. In a broader perspective, however, neither of these claims is actually particularly challenging.

The first claim, that there can be non-state law, can seem challenging vis-à-vis the currently dominant paradigm of law, and indeed the modern notion of state law cannot simply be imposed on non-state normative orders. ${ }^{1}$ Viewed in historical and comparative terms, it is the idea that all law is state law that is the exception; state law is the anomaly. Before the emergence of the modern state, all law was non-state law, and even during the reign of the state, this was long true outside the Western world and to a large extent within it. For many anthropologists and some sociologists, it has always been normal to refer to certain non-state orders as law.

The second claim, the plurality of laws, has been an empirical reality since different groups of humans interacted with each other. The state paradigm did not abolish this plurality, given that there have always been several states. The so-called Westphalian model with its emphasis on sovereignty provided a tool to invisibilize this plurality. Inside the state, sovereignty meant inclusivity; it became possible therefore to focus on one's own law and ignore all others. Outside the state, only states were relevant actors in the international realm, meaning again that it was possible to think (international) law as one system. But this invisibilization did not make the plurality of laws go away; it merely marginalized it.

The third claim, namely that laws overlap and interrelate, has received the least amount of attention, though it presents the greatest challenge for global legal pluralism. Theoretically, the question is how we should understand and conceptualize the interrelation of overlapping laws, as well as the question of whether laws can be thought independently of each other. Practically, the question is what it means for one legal order to recognize another order as law, and in what ways legal orders respond to each other. This chapter focuses especially on the practical question, but the relation with the theoretical question will become clear.

\footnotetext{
${ }^{1}$ Simon Roberts, "After Government?: On Representing Law Without the State," Modern Law Review 68, no. 1 (Jan. 2005): 1-24; more generally, see Ralf Michaels, "What is Non-State Law? A Primer," in Negotiating State and Non-State Law: The Challenges of Global and Local Legal Pluralism, ed. Michael A. Helfand (Cambridge: Cambridge University Press, 2015), 41-58.
} 
None of these questions, the last one included, is a new question for the discipline of law called conflict of laws. ${ }^{2}$ Indeed, the discipline derives one of its names from these conflicts. ${ }^{3}$ That discipline was long confined to private law and to relations between the laws of states, and may therefore have seemed inappropriate for situations of global legal pluralism. Nonetheless, if the concept of law is broadened to encompass non-state law, the natural consequence would be to simultaneously broaden conflict of laws to include conflicts with and between non-state laws. Mostly, this does not happen. At best, conflict of laws is named as one of many approaches towards managing plurality without attention to any specificities. At worst, it is ignored altogether. $^{4}$

But conflict of laws is not simply one of many mechanisms. Gunther Teubner suggests a unique position for conflict of laws: "In a world society with neither apex nor centre, there is just one way remaining to handle inter-constitutional conflicts-a strictly heterarchical conflict resolution." ${ }^{5}$ Horatia Muir Watt even suggests synonymy between conflict of laws and global legal pluralism. ${ }^{6}$ This chapter aims to support this claim that there is something specific about conflict of laws, and that conflict of laws is therefore specifically well equipped for problems of global legal pluralism. In section II, I discuss three other existing types of responses to plurality and their shortcomings for the demands of global legal pluralism. I then lay out, in section III, the core elements of a conflict of laws approach to global legal pluralism and survey some of the proposals that have been made for such an approach. In section IV, I discuss the four advantages that conflict of laws has over other approaches: its expertise, its epistemology, its technical nature, and its ethical content. Since all of this is rather abstract, I sketch an application to a concrete case in section $\mathrm{V}$, before I conclude in section $\mathrm{VI}$.

\section{Three Types of Responses to Plurality}

Once the existence of plurality and overlaps of laws is recognized, the question is how to respond to it. What is needed are both epistemological and practical responses. Epistemologically, it is necessary to understand and conceptualize the interrelatedness of laws. Practically, it is

\footnotetext{
${ }^{2}$ Ralf Michaels, "Global Legal Pluralism," Annual Review of Law \& Social Science 5 (Dec. 2009): 243-62, $248-49$.

${ }^{3}$ Conflict of laws is also called private international law.

${ }^{4}$ See, e.g., in an otherwise very impressive new doctoral thesis, R.C.M.E. Engels, "The Intertwinement of Legal Orders: A Critical Reconstruction of Theories of Jurisprudence" (PhD thesis, Erasmus University, Rotterdam, 2019), 70 ("How conflicts between norms from multiple legal orders that apply simultaneously are resolved remains unclear. Resolving these conflicts requires a political decision and goes beyond the descriptive scope of a positivist understanding of law.") See also Ralf Michaels, "A Symmetry of Asymmetries? A Private International Law Reconstruction of Lindahl's Work on Boundaries," Duke Journal of Comparative and International Law 29 no. 3 (Spring 2019) 405-422.

${ }^{5}$ Gunther Teubner, Constitutional Fragments: Societal Constitutionalism and Globalization (Oxford: Oxford University Press, 2012), 152.

${ }^{6}$ Horatia Muir Watt, "Jurisprudence Without Confines: Private International Law as Global Legal Pluralism," Cambridge International Law Journal 5, no. 3 (2016): 388-403; see also ibid. at 394 ("Normatively, or as a theoretical project, [conflict of laws] is perhaps the most promising avenue with which to approach contemporary jurisprudential questions dissociated from the domestic legal order.").
} 
necessary to find legal responses to the interrelatedness, especially to resolve, if only for the concrete case, existing conflicts.

The epistemological and the practical questions are themselves linked: certain types of practical questions relate to certain types of conceptualization of interrelatedness. It seems helpful, therefore, to focus on the epistemological background of different types of responses. Paul Schiff Berman has helpfully complied a whole list of such legal mechanisms: ${ }^{7}$ "dialectical legal interactions," margins of appreciation, limited autonomy regimes, subsidiarity schemes, hybrid participation arrangements, mutual recognition regimes, safe harbor agreements, and regime interactions within the international system. Here, these and similar approaches are grouped under three headings on the basis of their structure.

\section{A. Uniform Techniques}

An often-unquestioned assumption of conflicts is that their resolution must be made from a neutral position and with binding force for all parties to the conflict. Within one legal system, this neutral position exists within the law and is exercised by a state institution: the judge or the legislator. Between legal systems, it is not immediately clear where such a common law and a neutral position would exist. But this does not keep many scholars from looking for techniques to achieve this. I call these techniques uniform techniques because they aim to create, or presume, uniformity.

One type of uniform technique operates within the legal system of which the interrelated laws are part. Where different parts of a legal system are in conflict-because on their face they appear to give conflicting responses to similar situations-the legal system frequently provides responses as to which of them should prevail. The law has long recognized a number of interpretive presumptions to deal with such conflicts. According to the lex posterior rule, the later rule presumably trumps over the earlier one. According to the lex specialis rule, a specific rule trumps, where it applies, over a general rule. Under the lex superior rule, a higher rule (e.g., the Constitution) prevails over a lower rule (e.g., ordinary law). We can call these resolution techniques infrasystemic because they operate within one system.

A related type of technique does not presume that all interrelated laws belong to the same system. However, it presumes that a hierarchically superior law applies to both of them and is therefore capable of resolving conflicts between them with binding force for both. In this way, public international law can (or could) be used to resolve conflicts between different domestic laws, or state law could be used to resolve conflicts between different customary laws. We can call these techniques hierarchical.

Although both infrasystemic and hierarchical techniques originate within legal systems, both have been proposed to resolve conflicts between legal systems that exist in global legal pluralism. Infrasystemic techniques have been prominent especially in the debate about the fragmentation of international law. Analysts ask which of several different regimes was made later ${ }^{8}$ or which is

\footnotetext{
${ }^{7}$ Paul Schiff Berman, Global Legal Pluralism: A Jurisprudence of Law Beyond Borders (Cambridge: Cambridge University Press, 2012), 152-94.

${ }^{8}$ See Vienna Convention on the Law of Treaties art. 30(3), opened for signature May 23, 1969, 1155 U.N.T.S. 331.
} 
more specific (e.g., a specific bilateral investment treaty in relation to general European Union ("EU") law). ${ }^{9}$ Such infrasystemic techniques also provide the solution favored by the International Law Commission. ${ }^{10}$

In other areas of global legal pluralism, hierarchical techniques are favored. For example, Neil MacCormick resorts to international law to resolve conflicts between EU law and domestic law. ${ }^{11}$ Similarly, Mireille Delmas-Marty invokes international law and general principles to resolve conflicts within what she calls "ordered pluralism."12

Arguably, both types of technique are mostly inadequate for global legal pluralism. They presume conditions that exist for domestic law but are largely absent from the global plane. Infrasystemic techniques presume the existence of one legal system within which the interrelated laws exist, and they rely on that system and the presumption of a uniform lawmaker. The lex posterior rule assumes that a legislator, by passing new law, implicitly abolishes old and incompatible law. The lex specialis rule assumes that a lawmaker, by focusing specifically on a problem, thereby either specifies or abrogates the more general law it has made elsewhere. In the absence of a uniform lawmaker, both assumptions are unwarranted. Infrasystemic techniques must assume global law to create one great system. They are, in this sense, related to natural law theories. ${ }^{13}$ And they are subject to the same criticism that has been brought against natural law.

Hierarchical techniques are subject to a related critique. They must assume the existence of a superior law. They are therefore related to what John Griffiths has called "weak legal pluralism" a pluralism that takes place under the umbrella of a higher law. ${ }^{14} \mathrm{He}$ pointed out one problem with them: they are, in the end, not truly pluralist because they establish one hierarchically superior sE.g. et of rules or norms that resolves conflicts and thereby disentangles what was once entangled. His criticism of such solutions in and through state law, predominantly in the colonial and postcolonial context, was directed specifically at an ideology that sees state law as that higher law and as the ultimate arbiter of conflicts. As such, his criticism would not apply to those who seek solutions above or beyond the state. But in a generalized form, the criticism remains the same: a higher level must be found that is necessarily neutral and that makes the pluralist situation effectively go away. For hierarchical techniques to work, the hierarchy between the interrelated laws must be uncontroversially established. This may be the case within a legal system (e.g., the supremacy of the Constitution) but it is not, at least not automatically, outside.

\footnotetext{
${ }^{9}$ Christina Binder, A Treaty Law Perspective on Intra-EU BITs, Journal of World Investment \& Trade 17, no. 6 (2016) 964-983, 973-74.

${ }^{10}$ See, e.g., Int'I Law Comm'n, Fragmentation of International Law: Difficulties Arising from the Diversification and Expansion of International Law, U.N. Doc. A/CN.4/L.682, at para. 33 and passim (2006).

${ }^{11}$ Neil MacCormick, Questioning Sovereignty: Law, State, and Nation in the European Commonwealth (Oxford: Oxford University Press, 1999), 117-18. This is a modification of MacCormick's earlier view.

12 Mireille Delmas-Marty, Ordering Pluralism: A Conceptual Framework for Understanding the Transnational Legal World, trans. Naomi Norberg (Portland: Hart Publishing, 2009).

${ }^{13}$ Rafel Domingo, The New Global Law (Cambridge: Cambridge University Press, 2010).

14 John Griffiths, “What Is Legal Pluralism?,” Journal of Legal Pluralism \& Unofficial Law 18, no. 24 (1986): 1-55.
} 
Thus, the prevalence of international law over domestic law is not clear: from the perspective of domestic law, a domestic law that explicitly rejects international law will trump international law. The prevalence of human rights law over (state and non-state) laws may be normatively desirable, but critiques of human rights law mean that it cannot be presumed as the basis for resolving conflicts.

A second problem can be added to the first: a solution that creates different layers also creates conflicts between these layers. If the higher level is recognized as higher, it can resolve these conflicts by itself (in what French theory calls the hierarchy of norms). If it is not universally recognized, however, then the solution must be found in a yet higher level, like when MacCormick wants to resolve conflicts between state law and EU law on the basis of international law. ${ }^{15}$ This becomes an endless chain: now conflicts with international law must be resolved. Arguably, legal pluralism by definition bars resort to a higher level.

\section{B. Extralegal Techniques}

Proponents of infrasystemic and hierarchical techniques are often aware of the problematic assumption of uniformity they have to make. They make them, presumably, because they fear that the only alternative is lawlessness. Without infrasystemic or hierarchical techniques, it is often assumed, legal resolution of interrelation is not possible. This means that the risk of unresolved conflict is high, and the only hope to resolve conflict lies in extralegal mechanisms.

Many such extralegal mechanisms have been proposed. Among them is dialogue between different institutions (as advocated e.g., by Anne-Marie Slaughter) ${ }^{16}$ or "contrapunctual law" (as proposed by Miguel Maduro). ${ }^{17}$ The idea here is that institutions in charge of overlapping issues resolve their disagreement not through law but instead through a process of interaction, to bring their positions in accordance with each other. Such a process, though often recommended, is not without problems. ${ }^{18}$ One of the problems is that it may be inconclusive: it may overcome a conflict, but it may also fail. Another problem is simply that dialogue rarely takes place in a setting without power imbalances, and that therefore what looks like dialogue becomes in fact imposition. A third is that such extralegal mechanisms often go beyond the competences of respective institutions. Courts, existing within one legal system, are not automatically entitled to engage with institutions elsewhere. ${ }^{19}$

\footnotetext{
15 MacCormick, supra note 11.

${ }^{16}$ Anne-Marie Slaughter, A New World Order (Princeton, NJ: Princeton University Press, 2004); Alison L. Young, Democratic Dialogue and the Constitution (Oxford: Oxford University Press, 2017).

${ }^{17}$ Miguel Poiares Maduro, "Contrapunctual Law: Europe's Constitutional Pluralism in Action," in Sovereignty in Transition: Essays in European Law, ed. Neil Walker (Portland: Hart Publishing, 2003), 501-37.

${ }^{18}$ See also Karen Knop, Ralf Michaels, and Annelise Riles, "From Multiculturalism to Technique: Feminism, Culture, and the Conflict of Laws Style," Stanford Law Review 64 (Mar. 2012): 589-656, 648-49.

${ }^{19}$ Alex Mills \& Tim Stephens, "Challenging the Role of Judges in Slaughter's Liberal Theory of International Law," Leiden Journal of International Law 18, no. 1 (March 2005) 1-30; see also, e.g., Marshall v Fleming, [2014] NSWCA 64 (20 March 2014).
} 
A second suggestion, supported in particular by Nico Krisch, takes up the finding that dialogue may be inconclusive and that consensus may not always be desirable. ${ }^{20}$ In this perspective, conflict (and, by extension, entanglement) become actually attractive features because they provide spaces for politics, for struggle, for progress. This position seems more attractive from a normative position. But it concedes too quickly the claim that resolutions of conflicts between legal orders can only be resolved in extralegal ways.

\section{Decentralized Legal Techniques}

In the end, both uniform and extralegal techniques, different as they are in every other regard, rest on a common intuition, namely that legal resolutions of conflicts are possible only within a legal system. This presumption presents challenges for global legal pluralism. To allow for legal solutions (uniform legal techniques), one must give up on plurality. To allow for plurality, one must give up on legal solutions (extralegal techniques).

But the presumption is false. A third set of techniques exists thatis legal but not uniform. It consists of techniques that exist within each law and respond to real or potential interrelations in a decentralized way. Some such techniques operate purely unilaterally: they restrict a law's reach in order to avoid or minimize the risk of conflicts with other laws without an inquiry as to whether such conflicts actually occur. For example, under the presumption against extraterritoriality, laws are not normally applied outside a state's territory, regardless of any other law's conflicting claim to regulation. Other techniques respond to actual conflicts through a unilateral restriction of their scope. An example is comity, an umbrella concept for various ways in which courts refrain from exercising jurisdiction or applying their domestic law in view of regulatory interests of another law. ${ }^{21}$

These mechanisms deserve a longer and more careful analysis than I am able to provide right now, especially given the differences between them. Some fall more into the nonlegal category above (especially what Berman calls dialectical legal interactions, to some extent also the hybrid participation arrangements). Others invoke supranational values very much akin to the hierarchically superior model discussed above. ${ }^{22}$

Yet all of them share, I believe, two shortcomings, which relate them to the two other types of techniques named before. First, they all incorporate attempts to minimize conflict, to reduce its occurrence. They are techniques designed to overcome and resolve conflict; nonresolution is viewed as inferior. This is indeed a position taken by legal theorists arguing from ideas of internal coherence of law. But, as discussed above, it is not clear a priori that the uniform resolution of a

\footnotetext{
${ }^{20}$ Nico Krisch, Beyond Constitutionalism: The Pluralist Structure of Postnational Law (Oxford: Oxford University Press, 2010).

${ }^{21}$ See, e.g., William S. Dodge, “International Comity in American Law," Columbia Law Review 115, no. 8 (Dec. 2015): 2071-141.

22 See Alexis Galán and Dennis Patterson, "The Limits of Normative Legal Pluralism," review of Global Legal Pluralism: A Jurisprudence Beyond Borders, by Paul Schiff Berman, International Journal of Constitutional Law 11, no. 3 (July 2013): 783-800.
} 
conflict is preferable. ${ }^{23}$ The idea that the uniform resolution of conflicts is preferable is a remnant of infrasystemic thinking. Between systems, it can lead to underregulation: where each system unilaterally withdraws to avoid conflicts, regulatory gaps emerge.

Second, all these techniques are, from a purely technical perspective, relatively simplistic devices. By and large, most of them consist merely of restraint devices: a normative order restrains its own reach in view of another, grounded, typically, in certain policy considerations. This puts a lot of argumentative weight on these policy considerations, and means, on the other hand, and for the same reason, a withdrawal of law itself from addressing the truly hard questions. In this regard, these techniques are reminiscent of the extralegal techniques discussed before: they yield answering the really hard questions to mechanisms that are not strictly legal.

\section{Conflict of Laws as Technique for Plurality}

So much for other techniques. Now what about conflict of laws? It consists, traditionally, of three subfields. Jurisdiction deals with the competence of courts to deal with cases in view of their connections to several legal systems. Choice of law deals with the question which law is applicable in such situations. Recognition and enforcement of judgments, finally, deals with the question to which extent decisions of one legal system are given force in another legal system. The most important of these three for purposes of this chapter is choice of law, and so I will confine myself to this here.

\section{A. Techniques}

How does conflict of laws operate? It is hard to answer this question in the abstract, given the almost dizzying variety of methodological approaches that exist in the discipline. ${ }^{24}$ Whether there is an essence to conflict of laws remains, for the time being, an open question. Nonetheless, it may be possible to list a number of elements that characterize most approaches to conflict of laws. ${ }^{25}$ The most important element, and one that distinguishes conflict of laws from the other techniques, is that choice of law and jurisdiction are separated. This means that a court may have jurisdiction but nevertheless not apply its own law. It means, more importantly, that a court may apply a foreign law. The deference to the foreign law is therefore not merely one of restraint but one of embrace. This distinction is crucial. Approaches of restraint resolve conflicts between laws through disentanglement: if each law confines itself, it is hoped that the overlap no longer takes place. Conflict of laws, by contrast, operationalizes the entanglement and continues it through the institutions of one law applying the rules of another law. Foreign law is rarely applicable in toto: the focus is on the resolution of a concrete conflict, and the applicability of foreign law is

\footnotetext{
${ }^{23}$ See Monique Hakimi, The Work of International Law, Harvard Journal of International Law Vol 58, no. 1(Winter 2017) 1-46.

${ }^{24}$ See Symeon Symeonides, Private International Law: Idealism, Pragmatism, Eclecticism (Leiden, Netherlands: Brill-Nijhoff, 2017).

${ }^{25}$ For an earlier, more comprehensive, attempt, see Knop, Michaels, and Riles, "From Multiculturalism to Technique," supra note 18, 627-56.
} 
limited to the relevant rules. As a consequence, a court may end up applying different laws in the same case: a husband's tort liability to his wife may include the law of Italy (where the couple lives), the law of France (where the tort happened), and the law of Germany (where the case is litigated).

A second important element in conflict of laws is that it is, with rare exceptions, domestic law. Each legal system determines, for itself, the relation between itself and another law. Another legal system may come to different conclusions. Under New York's conflict-of-laws regime, for example, French law may be applicable to a certain transaction, whereas French conflict of laws may designate New York law to apply. A conflict of laws is thus resolved but not in a uniform matter. The discipline has developed the doctrine of renvoi as a partial response. Under the doctrine, courts in one legal system may take into account also the conflict-of-laws regime of the other legal system. This doctrine can sometimes minimize the potential for conflicting results, but not always: In my example, if both the courts in New York and France were to take into account each other's conflict-of-laws regime, they would each end up with the application of their own law, and the conflict would remain.

A third important element, finally, is the technical character of conflict of laws. Other doctrines ultimately end up with a balancing of respective interests of the different laws in order to resolve a conflict. Conflict of laws, by contrast, is mostly anathema to such balancing, and with good reason, because balancing can properly only be done within one system. Instead, most methods of conflict of laws require a high level of technicality in order to determine the applicable law. For example, under the so-called traditional method, a court will have to go through various steps. It will first have to characterize the issue in question: does it belong to tort law, contract law, or marriage law? Doing so provides the court with a connecting factor, for example the place of the tort, and leads to the second step of localizing: where is the place of this tort? If I send you poison by mail and you take it and get sick, is the place of the tort the place where I put the poison in the envelope, the place where you take it, or the place where the poison finally works? The applicable law will be the law of that place, but the third step-application-includes some further issues: should the conflict of laws regime of the foreign state be considered (renvoi)? Should foreign law remain inapplicable because it violates policies of the forum (public policy exception)?

The extremely technical character of this method, combined with its blindness to the substance (except in the public policy exception) have led to the development of many other methods. One of these is interest analysis: courts are required to determine which legal systems are interested in the application of their own laws and then resolve remaining conflicts. Instead of balancing these interests, a court will frequently determine which of them would be more impaired by nonapplication of its law. ${ }^{26}$ Although this approach may appear simple and untechnical, making it applicable may require a fair amount of technicality. Here are the rules the New York courts developed for the specific case of liability in view of so-called guest statutes: ${ }^{27}$

\footnotetext{
${ }^{26}$ William F. Baxter, "Choice of Law and the Federal System," Stanford Law Review 16, no. 1 (Dec. 1963$):$ 1-42.

${ }^{27}$ Neumeier v. Kuhner, 286 N.E.2d 454, 457-58 (N.Y. 1972) (quoting Tooker v. Lopez, 249 N.E.2d 394,399 (N.Y. 1969)).
} 
"1. When the guest-passenger and the host-driver are domiciled in the same state, and the car is there registered, the law of that state should control and determine the standard of care which the host owes to his guest.

2. When the driver's conduct occurred in the state of his domicile and that state does not cast him in liability for that conduct, he should not be held liable by reason of the fact that liability would be imposed upon him under the tort law of the state of the victim's domicile. Conversely, when the guest was injured in the state of his own domicile and its law permits recovery, the driver who has come into that state should not-in the absence of special circumstances-be permitted to interpose the law of his state as a defense.

3. In other situations, when the passenger and the driver are domiciled in different states, the rule is necessarily less categorical. Normally, the applicable rule of decision will be that of the state where the accident occurred but not if it can be shown that displacing that normally applicable rule will advance the relevant substantive law purposes without impairing the smooth working of the multistate system or producing great uncertainty for litigants."

\section{B. Existing Proposals}

This idea that conflict of laws, even if in a modified version, could be made useful for issues of global legal pluralism has found at least some supporters in existing scholarship. Many of these have been developed in the context of international and supranational law; they may therefore not be applicable in other areas without modifications. ${ }^{28}$

Paul Schiff Berman has proposed such a modification. ${ }^{29}$ His suggestion is that conflict of laws must move beyond both a strict preference for the lex fori and strict territorialism in order to account for the requirements of global legal pluralism. Legal orders (and the actors in them) should be more willing than they are to defer to other regulatory interests, even if those are the interests of non-state groups and their normative systems. Berman refrains from providing concrete rules or solutions and emphasizes that the general openness to deference is more important than the resolution of concrete conflicts.

A more concrete expansion of conflict-of-laws approaches into the realms of international and especially European law has for some time been a focus in the work of Christian Joerges and others. ${ }^{30}$ Joerges uses a political understanding of conflict of laws, based on ideas of interest

\footnotetext{
${ }^{28}$ For the argument that supranational legal pluralism is altogether different from global legal pluralism, see, e.g., Brian Z. Tamanaha, "The Promise and Conundrums of Pluralist Jurisprudence," Modern Law Review 82, no. 1 (Jan. 2019): 159-79.

${ }^{29}$ Berman, supra note 7, 191.

${ }^{30}$ E.g., Conflict of Laws and Laws of Conflict in Europe and Beyond: Patterns of Supranational and Transnational Juridification, ed. Rainer Nickel (Antwerp: Intersentia Publishing, 2010); Christian Joerges, "The Idea of a ThreeDimensional Conflicts Law as Constitutional Form," in Constitutionalism, Multilevel Trade Governance and International Economic Law, eds. Christian Joerges and Ernst-Ulrich Petersmann (Portland: Hart Publishing, 2011);
} 
analysis, towards a constitutionalization of plural regimes. He develops this approach against the insight that deterritorialization and globalization weaken the regulatory force of the state, yet supranational regulation is not an option. His model is three-dimensional; its three dimensions concern interdependence, the regulatory state, and the turn to governance, in particular the inclusion of non-state governance. It combines elements of interest analysis with Habermasian ideas on deliberation and the concept of comitology and thus goes beyond strictly legal towards an interdisciplinary understanding.

Like Joerges, Horatia Muir Watt has proposed that conflict of laws must both endorse a governance function and become interdisciplinary in order to remain capable of dealing with issues of global legal pluralism. ${ }^{31}$ She suggests that conflict of laws' traditional distinction between law and politics, between public and private, has made the discipline blind to its political implications. What is necessary, in her view, is to move conflict of laws away from its obsession with technicalities and instead include political considerations: human rights obligations of private actors, private regimes and their quasi-lawmaking capacities, and questions of governance at large.

If the focus of these two European authors is one of politicization and deformalization, some authors in North America, perhaps against the experience with the antiformalist US conflict of laws, go a slightly different path. Annelise Riles has suggested, based on a cultural understanding of law, to link conflicts of laws with cultural conflicts and thereby expand the scope of the discipline. ${ }^{32}$ Following this, Karen Knop, Ralf Michaels and Annelise Riles also propose a conflictof-laws response to issues of conflict and overlap outside of the realm of private law, for example for the relation between domestic and international law, that between feminism and multiculturalism, and that between financial regulators in the world. ${ }^{33}$ Unlike others who deemphasize the need for multidisciplinarity and a rejection of technicality, they view the value of conflict of laws precisely in its technical character as a way to deal with intrinsic politics. ${ }^{34}$

Much of the discussion about conflict-of-laws approaches has concerned the fragmentation of international law. Already in the 1950s, Wilfred Jenks suggested such an approach for the conflict

Christian Joerges, Poul F. Kjaer, and Tommi Ralli, “A New Type of Conflicts Law as Constitutional Form in the Postnational Constellation," Transnational Legal Theory 2, no. 2 (2011): 153-65.

${ }^{31}$ Horatia Muir Watt, "Private International Law Beyond the Schism," Transnational Legal Theory 2, no. 3 (2011): 347-428; Horatia Muir Watt, "Jurisprudence Without Confines," supra note 6; Horatia Muir Watt, "Discours sur les méthodes du droit international privé (Des formes juridiques de l’inter-alterité)," (The Hague: Hague Academy 2019).

${ }^{32}$ Annelise Riles, “Cultural Conflicts," Law \& Contemporary Problems 71, no. 3 (Summer 2008): 273-308.

${ }^{33}$ Karen Knop, Ralf Michaels, and Annelise Riles, "International Law in Domestic Courts: A Conflict of Laws Approach," American Society of International Law Proceedings 103 (2009): 269; Knop, Michaels, and Riles, "From Multiculturalism to Technique," supra note 18; Karen Knop and Annelise Riles, "Space, Time and Historical Injustice: A Feminist Conflict-of-Laws Approach to the 'Comfort Women' Settlement," Cornell Law Review 102, no. 4 (May 2017): 853-927.

${ }^{34}$ Ralf Michaels, "Post-Critical Private International Law: From Politics to Technique," in Private International Law and Global Governance, eds. Horatia Muir Watt and Diego Fernández Arroyo (Oxford: Oxford University Press, 2014), 54-67. 
of treaties. ${ }^{35}$ This suggestion remained largely isolated, however; most scholars preferred the infrasystemic techniques as adopted also in the International Law Commission, sometimes also extralegal mechanisms. ${ }^{36}$ Against this trend, Gunther Teubner has suggested to understand and resolve conflicts between different functional regimes within international law through conflictof-laws techniques. ${ }^{37}$ He suggests a modification: connection factors must be functional as opposed to territorial, and the result of the method is not the application of one or the other regime but instead the creation of a new substantive rule. Dirk Pulkowski favors the resolution of such conflicts on the basis of which regime would be more impaired by non-application. ${ }^{38}$ This approach is known from traditional conflict of laws, where it was originally developed for conflicts within a federal system, to be administered from a hierarchically superior position. ${ }^{39}$ Michaels and Pauwelyn, finally, suggest that different constellations yield different responses. ${ }^{40}$ They suggest that the uniform techniques favored by the International Law Commission work well where regime conflicts exist within one functional regime. Within trade law, it may make sense to apply a lex specialis approach. As between functional regimes (like environmental law and trade law), a common system is arguably lacking, so a conflict-of-laws approach is more promising.

\section{The Fourfold Advantage of Private International Law}

It is not necessary, in the context of this chapter, to select a particular approach. It is, however, worth discussing in what way conflict of laws is specifically well equipped for issues of global legal pluralism. Four different factors can be named: the discipline's experience with plurality, its epistemological take on plurality, its specifically technical character, and its ethical potential. Each will here be discussed in turn.

${ }^{35}$ C. Wilfred Jenks, "The Conflict of Law-Making Treaties," British Year Book of International Law 30 (1953): 401 ; see also Philip Jessup, Transnational Law (New Haven, CT: Yale University Press, 1956).

${ }^{36}$ See Anne Peters, "The Refinement of International Law: From Fragmentation to Regime Interaction and Politicization," International Journal of Constitutional Law 15, no. 3 (July 2017): 671-704.

${ }^{37}$ Andreas Fischer-Lescano and Gunther Teubner, "Regime-Collisions: The Vain Search for Legal Unity in the Fragmentation of Global Law," Michigan Journal of International Law 25, no. 4 (2004): 999-1046; Gunther Teubner and Peter Korth, "Two Kinds of Legal Pluralism: Collision of Transnational Regimes in the Double Fragmentation of World Society," in Regime Interaction in International Law: Facing Fragmentation, ed. Margaret A. Young (Cambridge: Cambridge University Press, 2012), 23; Teubner, supra note 5, $150 \mathrm{ff}$.

${ }^{38}$ Dirk Pulkowski, The Law and Politics of International Regime Conflict (Oxford: Oxford University Press, 2014), $329 f f$.

${ }^{39}$ William F. Baxter, "Choice of Law and the Federal System," Stanford Law Review 16, no. 1 (Dec. 1963): 1-42, supra $\mathrm{n}$

${ }^{40}$ Ralf Michaels and Joost Pauwelyn, "Conflict of Norms or Conflict of Laws?: Different Techniques in the Fragmentation of Public International Law," Duke Journal of Comparative \& International Law 22, no. 3 (2012): 349-76; similarly, Pulkowski, supra note 38. 


\section{A. Experience}

The first reason is simple and straightforward: the most appropriate discipline to deal with a plurality of legal orders is the discipline that was established for this very purpose, and that is conflict of laws. Modern conflict of laws is a discipline with many hundreds of years of experience and, in consequence, expertise. There is no reason to invent a new discipline to take its stand.

Opponents often point to two alleged shortcomings of conflict of laws: its (sometimes exaggerated) complexity and the fact that there is no agreement in the discipline as to the proper method. These are odd criticisms. Though conflict of laws is not as impossibly complex as it is sometimes described by those who have not seriously engaged with it, it is undeniably more complex than many other disciplines. This is, however, a consequence of the complexity of its object. Reasoning between laws is unavoidably more complex than reasoning within one system. The disagreement about the proper method should be viewed as an advantage, not a disadvantage. It is precisely the wealth of different methods and tools, the variety in its experience, that qualifies private international law to deal with legal pluralism. In this sense conflict of laws is less like an ordinary discipline (like contract law) and more like a foundational subject like legal philosophy (with which it shares the stance that laws are its object).

One main, but erroneous, argument against the usefulness of conflict of laws for global legal pluralism is its narrow focus. The discipline, in its current form, is confined in two ways. First, it concerns only conflicts between regimes of private law: contract, tort, family, and the like. Public law is excluded and left to other devices more in accordance with the decentralized legal mechanisms described above. Second, conflict of laws is traditionally confined to conflicts between state laws. Both these constraints are significant for global legal pluralism, which is not confined to private law (and indeed challenges the public/private distinction altogether) and which operates importantly with non-state laws.

But it would be is a fundamental mistake to conflate conflict of laws as it currently exists with conflict of laws as a discipline. Conflict of laws is a discipline whose object is law; it is therefore almost necessarily shaped in different times (and places) by the respective dominant concept of law. ${ }^{41}$ The fact that conflict of laws has adapted to the state paradigm of law when this was predominant in the nineteenth and twentieth centuries should rather serve as a sign for the discipline's adaptability. All in all, the discipline's history reveals an almost mesmerizing plethora of different methodical and conceptual approaches: a treasure trove for new ideas.

There is little doubt that conflict of laws can be extended beyond its traditional confinement to domestic private law. As to the restriction to private law, this is a consequence of the importance of sovereignty under the state paradigm. It was thought that conflicts between public laws were conflicts between sovereign commands that could be resolved only through diplomacy-the origin for the uniform and extralegal mechanisms discussed above. The confinement of private

\footnotetext{
${ }^{41}$ See Eugen Ehrlich, "Internationales Privatrecht," Deutsche Rundschau 126 (1906): 419-33; for French, see "Les tendances actuelles du droit international privé," Revue de droit international privé et de droit penal international 4, no. 6 (1908): 902-24; see also Ralf Michaels, "The Re-State-Ment of Non-State Law: The State, Choice of Law, and the Challenge from Global Legal Pluralism," Wayne Law Review 51 (2005): 1209-59, $1244 \mathrm{ff}$.
} 
international law to private law is thus closely linked to the rise and fall of the public/private distinction in law more generally. In the world of global legal pluralism, sovereignty has become significantly more complex: it is often shared and overlapping, rarely absolute and complete as it was under the Westphalian model. ${ }^{42}$ Arguably, after the rise of public law, we can see a return to the private. ${ }^{43}$ Conflict of laws matches this world. ${ }^{44}$

A related question is whether conflict of laws can adapt to non-state laws and regimes. This is not merely done automatically by expanding the notion of what counts as law. The "law" in traditional conflict of laws is state law: recognizing other normative regimes as law in a jurisprudential sense does not automatically make them apt for conflict of laws. ${ }^{45}$ For example, non-state law is often not as comprehensive as state law. What would we do with a traditional rule that designates the tort law of a legal order as applicable when that system has no tort law? Moreover, non-institutionalized laws often provide no clear answers to legal questions without prior discussion within the community; this creates problems when such issues are adjudicated in another legal system. In response, it may be necessary to go back to conflict-of-laws and its experience with other non-state law. But that experience exists.

\section{B. Epistemology}

Conflict of laws is apt for global legal pluralism for a second reason: it provides an adequate epistemology. It accounts for what Griffiths calls the reality of legal pluralism better than any other discipline. This may sound like a curious claim: we do not usually think of legal disciplines as epistemological endeavors. But conflict of laws not only rests on but also encapsulates such an epistemology. Recall the first of the three claims of global legal pluralism discussed earlier: that non-state law is also law. This question is often discussed as an ontological one and thus becomes one about the nature of law. Conflict of laws sidesteps this ontological question in favor of an epistemological approach. Its question is not whether a foreign order is law, but whether it should be recognized as such for the purposes of conflict of laws. ${ }^{46}$ The question of what is law is answered not from the nature of the normative order itself, but instead from the perspective of the forum asked for recognition. And it is turned from an ontological question to an ultimately pragmatic one. Put differently: there is no ontological truth (no is/ought crossover) that forces a judge, say, in country $B$, to recognize legal order A as law. Instead, it is a decision taken by and within country $B$.

\footnotetext{
42 See Nicole Roughan, Authorities: Conflicts, Cooperation, and Transnational Legal Theory (Oxford: Oxford University Press, 2013).

${ }^{43}$ Ralf Michaels and Nils Jansen, "Private Law Beyond the State?: Europeanization, Globalization, Privatization," American Journal of Comparative Law 54 (2006): 843-90, 871-73.

${ }^{44}$ See also Ralf Michaels, "Towards a Private International Law for Regulatory Conflicts?," Japanese Yearbook of International Law 59 (2017): 175-201.

${ }^{45}$ See Michaels, "The Re-State-Ment of Non-State Law," supra note 41.

${ }^{46}$ See Ralf Michaels, "Law and Recognition-Towards a Relational Concept of Law," in In Pursuit of Pluralist Jurisprudence, eds. Nicole Roughan and Andrew Halpin (Cambridge: Cambridge University Press, 2017 ), 90-115.
} 
Related to this is a second reason why conflict of laws is epistemologically attractive: it is positional. Because conflict of laws exists within each domestic law, its perspective is always only that of this particular legal system. If a French court recognizes a rule of Palestinian law as applicable, it makes a claim with regard to the French system, but not a universalist claim. Conflict of laws thereby avoids the "view from nowhere," which is so especially harmful to legal pluralism - the idea that although law is plural and non-hierarchical, there exists a hierarchically superior epistemological position from which legal pluralism can be understood objectively.

Finally, there is a third epistemological advantage: questions in conflict of laws are concrete and confined to what matters for the actual issue under consideration: what matters is the nature of the Lebanese rule on comparative negligence is valid, not the nature of Lebanese law at large. Thus, one big question of global legal pluralism - whether law must be a system - can often be avoided as simply irrelevant.

\section{Technique}

Conflict of laws has a third advantage over other approaches: its technical character. Of course, this technical character is often viewed as a disadvantage. The most widespread criticism is that technique obfuscates underlying issues of politics by pretending that solutions to conflicts are dictated through a neutral, mechanical process and not as a result of political decisions made between different conceptions of the right and the good. Opponents of conflict of laws use this as a reason to favor other techniques for the resolution of conflicts, despite their inadequacies. ${ }^{47}$ Even some proponents of conflict of laws concede the criticism and suggest that conflict of laws must become less technical in order to respond adequately to the challenges of global legal pluralism. ${ }^{48}$

However, both parts of the criticism - that technicality makes the politics invisible and that technicality is inadequate to resolve ultimately political conflicts-can be refuted. As to the first criticism, it is certainly true that a naïve use of techniques can invisibilize the underlying politics, a criticism that has long been made of legal formalism. But this is not necessarily the case. The language of conflict of laws can be used in an "as if" mode: problems can be described in a technical way as if they were unpolitical, although we are all aware that they are not. ${ }^{49}$ (This is analogous to the way in which we can refer to a dot of chalk on the board as if it were a dot, although we know it is not.) Or, even more strongly, we can understand the technical language of conflict of laws itself as a political language. We can understand its technical elementsconnecting factor, personal law, characterization, dépeçage-as concrete expressions of otherwise abstract political issues - center of authority, identity, shared authority. ${ }^{50}$

\footnotetext{
47 See supra Section II.

${ }^{48}$ E.g. Muir Watt, Schism, supra $\mathrm{n}$

${ }^{49}$ Knop et al., Multiculturalism, supra $\mathrm{n}_{\text {__ }}$, at 638-40.

${ }^{50}$ Michaels, Post-Critical, supra n. __ at 66-67.
} 
The second criticism - namely that the field's technical character makes it inapt for the resolution of ultimately political conflicts - is equally faulty. Its presumption-that a political conflict must be resolved with political means-is not only unwarranted but arguably demonstrably false. Law resolves political conflicts with technical means all the time; that is one of its main functions. As between different entities, a political solution is often impossible because of the absence of a proper mechanism (like majority vote) that exists only within, not between, legal orders. As such, then, political conflicts would frequently be irresolvable unless they are turned into technical conflicts. Technicality, counterintuitively, becomes a tool in the hand of the critical analyst. It is in this sense that Koskenniemi has proposed a return to formalism in public international law and that conflict of laws can resolve conflicts precisely because of its technical nature. Again, this happens in an "as if" mode: the political conflict is of course never merely a technical one, and the solution of the technical conflict alone is not the same as the solution of the political conflict. At the same time, the technical character of the discipline may provide a better reason for the acceptance of its results.

\section{Ethic}

Finally, private international law can be understood as an ethic, namely an ethic of engagement. It is not always appreciated that private international law, in this way not unlike public international law, has always served the overcoming of enmity. ${ }^{51}$ What distinguishes it is the way in which private international law does this.

Within private international law there is a discussion as to its relation to justice and values. As for justice, the question is whether conflict of laws is neutral with regard to justice, whether it furthers substantive justice, or whether its role lies in the achievement of a specific kind of justice called conflicts justice. ${ }^{52}$ In parallel, the question of values has three parts: whether conflict of laws is "value-free," whether it furthers substantive values, or whether there are specific conflicts values at stake. ${ }^{53}$ But the claim here is not merely that conflict of laws can further certain ethical values, but that it can itself function as an ethic.

Horatia Muir Watt has recently emphasized the ethical potential of conflict of laws. ${ }^{54}$ She distinguishes three ways in which law can deal with foreign law: intolerance, tolerance, and hospitality. Private international law, she argues, should not exclude foreign law in the way that

\footnotetext{
${ }^{51}$ See, e.g., Götz Schulze, "Die Überwindung von Feindschaft durch Kollisionsrecht," in Akten der Griechischen Gesellschaft für Rechtsphilosophische und Rechtshistorische Forschung, vol. 7b, eds. Strangas et al. (Baden-Baden: Nomos, 2016), 1097-128; Berman, supra note 7, 145-46 (referencing Chantal Mouffe).

${ }^{52}$ For the debate, see Symeon Symeonides, "Material Justice and Conflicts Justice in Choice of Law," in International Conflict of Laws for the Third Millennium: Essays in Honor of Friedrich K. Juenger, eds. Patrick J. Borchers and Joachim Zekoll (Leiden, Netherlands: Brill-Nijhoff, 2001), 125; Spyridon Vrellis, "Conflit et coordination de valeurs en droit international privé: A la recherche de la justice," Rec. des Cours 328 (2007): 175.

${ }^{53}$ For the debate, see Ralf Michaels, "Private International Law and the Question of Universal Values," in The Continuing Relevance of Private International Law and Its Challenges, eds. Franco Ferrari and Diego P. Fernández Arroyo (Cheltenham, UK: Edward Elgar, forthcoming).

${ }^{54}$ Horatia Muir Watt, "Hospitality, Tolerance, and Exclusion in Legal Form: Private International Law and the Politics of Difference," Current Legal Problems 70, no. 1 (2017): 111-47.
} 
lex forism (the strict priority of the law of the forum) would require. Nor should it merely tolerate foreign law in the way of traditional multilateralism - unlike other doctrinal tools of jurisdictional self-restraint. Rather, drawing on Derrida, she argues that private international law creates a space of hospitality for the foreign law. ${ }^{55}$ Conflict of laws becomes the discipline that deals with inter-alterity.

This is promising especially for global legal pluralism. Exclusion of the foreign, at least as a principled approach, is indeed incompatible with the ethical requirements and demands of legal pluralism. So is, in fact, tolerance, which is expressed especially in the doctrine of comity. Tolerance suffers from two big shortcomings. First, it carries within itself an element of disdain for the other: we must tolerate only what we disagree with. Second, it is mostly incapable of formulating the precise limits of toleration in a rational way.

However, hospitality, which Muir Watt prefers, comes also with its own constraints. Derrida formulates a demand of unconditional hospitality: the host is required to offer literally everything to his guest. ${ }^{56}$ Applied to conflict of law this would mean deference to foreign law without limits. This seems too demanding, and indeed Muir Watt, when she translates the ethical requirement into a methodological approach, does not go as far. As a consequence, however, what she uses is no longer hospitality.

The better approach, borrowed from another of Levinas's students, namely Waldenfels, is arguably responsivity. ${ }^{57}$ Responsivity suggests that the mere existence and presence of the foreign law already puts an ethical demand on us and requires us to respond-without determining how that response looks. An ethic of responsivity does not refuse the other, it does not accept it unconditionally, and it also does not draw necessarily arbitrary a priori limits of tolerance. Instead, an ethics of engagement takes the other seriously as simultaneously other and directed to us-as simultaneously separate and entangled. ${ }^{58}$ We are required to take seriously what the foreign law says and needs, to relate it to what we say and need, to find a solution that in the end is necessarily ours but at the same time informed by and caring for the position of the other. It does not prioritize compromise, but it does require understanding and compassion.

\footnotetext{
${ }^{55}$ See also Paul Schiff Berman, "Conflict of Laws and the Legal Negotiation of Difference," in Law and the Stranger, eds. Austin D. Sarat, Martha Umphrey \& Lawrence Douglas (Stanford: Stanford University Press, 2010).

${ }^{56}$ Of Hospitality-Anne Dofourmantelle Invites Jacques Derrida To Respond (Stanford: Stanford University Press 2000).

${ }^{57}$ Ralf Michaels, "Private International Law as an Ethic of Responsivity," in Diversity and Integration in Private International Law, eds. Verónica Ruiz Abou-Nigm and María Blanca Noodt Taquela (Edinburgh: Edinburgh University Press, 2019).

58 Bernhard Waldenfels, The Question of the Other (Albany: State University of New York Press, 2007), 21ff; Bernhard Leistle, "Responsivity and (Some) Other Approaches to Alterity," Anthropological Theory 16, no. 1 (Mar. 2016): 48-74.
} 
The mode of this ethic, importantly, is not dialogue, tolerance, or compromise. ${ }^{59}$ The ethic of engagement involves listening and understanding. But it remains a unilateral approach: it asks from us, not from the other; it creates an engagement within the legal order, not an extralegal outreaching to the other. The mode of this ethic is, somewhat counterintuitively, technique: an ethics of engagement formulates ways and strategies in which the other can be understood and responded to without denying its otherness.

\section{Conflicts for Global Legal Pluralism: An Example}

If all of this is somewhat abstract; an example may be able to demonstrate some of the promises of a conflict-of-laws approach. In the well-known Kadi affair, the legal question before the European Court of Justice ("ECJ") was one of conflict (or, if you will, of entanglement). ${ }^{60}$ The United Nations Security Council ("UNSC") had, in a Resolution, required all UN member states to freeze the assets of certain individuals allegedly related to al Qaeda and the Taliban. It offered no process to allow individuals on the list to question their inclusion. The EU had implemented the UNSC Resolution in an EU Regulation. This regulation was now challenged as being incompatible with European human rights.

Through the process before European courts, three approaches were tried. The Court of First Instance refused to review the EU regulation in light of the assumed superiority and bindingness of international law. ${ }^{61}$ Additionally, it analyzed whether the UNSC Resolution was compatible with international law principles of due process and found that it was. Advocate General Maduro argued against such a subjection of EU law to international law and advocated, instead, for a complex interactive approach along the line of the Solange decisions of the German Constitutional Court: EU institutions should defer to the UNSC as long as fundamental human rights were followed. The ECJ, finally, rejected both approaches in favor of a priority of EU law: the ECJ did not have to measure its own law against international law, and the Regulation could be annulled.

The approaches have been analyzed from the perspective of international law as representing monism (Court of First Instance), dualism (ECJ), and some kind of intermediate solution (Advocate General). They could more fruitfully be analyzed as conflict-of-laws approaches. From this perspective, the ECJ decision represents the kind of lex forism, or exclusion, that Muir Watt rejected: a court that refuses to engage with the other law and applies, ultimately, only its own law, in rejection of the other. The decision of the Court of First Instance, by contrast, is (or

\footnotetext{
${ }^{59}$ See Knop, Michaels, and Riles, “From Multiculturalism to Technique," supra note 18, 648-52.

${ }^{60}$ For an excellent summary and analysis, see Gráinne de Búrca, "The European Court of Justice and the International Legal Order After Kadi," Harvard International Law Journal 51, no. 1 (Winter 2010): 1-49. I focus here only on the matter called Kadi I and ignore subsequent developments.

61 Judgements of the CFI of September 21, 2005 in Ahmed Ali Yusuf and Al Barakaat International Foundation v Council of the EU and Commission of the EC (AI Barakaat CFI Judgement), Case T-306/01, and Yassin Abdullah Kadi v Council of the EU and the Commission of the EC (Kadi CFI Judgement), Case T-315/01 (OJ 2005 C 281, at 17).
} 
appears to be) one of total hospitality (or of lex causae): it prioritizes the foreign law on the basis of its presumed hierarchical superiority over its own law. Only the Advocate General defends an approach that approximates an actual conflicts approach, which is one of limited deference.

Redrafting the approaches in this way also helps to see some weaknesses in the approaches that have, as far as I can see, been underestimated so far. The ECJ refusal to account for international law has seen the brunt of the criticism. A conflict-of-laws analysis can divide this critique into a justified and an unjustified part. It is indeed inappropriate to reject a priori the normative claims of other legal orders (in this case international law), but it is not inappropriate to reject its normative claim, in its entirety, a posteriori. Conflict of laws regularly ends up in the exclusion of one law in favor of the other.

A conflict-of-laws analysis can find weaknesses in the approach of the Court of the First Instance, too. First, the presumed hierarchy of international law over EU law would need to be grounded not in some objective truth but in a specific conflicts rule that is intrinsic to EU law. This is so because hierarchy rules exist only within one legal system, not between them. Second, when the court starts interpreting international law, it falls into the problems that are well-known from private international law of interpreting and applying foreign law.

In many ways, the Advocate General's approach is the most attractive from a conflict-of-laws perspective because it starts with the possibility that either law could be applicable, and it invites an engagement. At the same time, arguably, viewing it as a conflict-of-laws approach demonstrates the relative technical paucity of the approach. Essentially, what we find, from the perspective of law, is a two-step approach. On a first step, the adequacy of the foreign law is determined based on formal criteria (in this case hierarchical superiority). In the second, the deference is denied if it undermines core values of EU law. This is, in essence, a system of a choice-of-law rule combined with a public policy exception. Numerous other tools available in conflict of laws-characterization, renvoi, adaptation-are ignored, as is the experience that emerges from hundreds of years of fruitful methodological struggles with these doctrines. ${ }^{62}$

A richer approach might find a more technical and therefore more adequate solution. It might, for example, restrict the deference owed to international law to matters of substance (e.g., who is on the list and what the consequences of that are) and maintain issues of procedure (including the possibility of challenging the list) to the referring system, in this case EU law. This would be in accordance with a classical distinction between matters of substance (for which foreign law may be applicable) and matters of procedure (for which, in principle, lex fori governs). It might consider a renvoi from international law, insofar as the UNSC typically leaves matters of implementation to the member states. It might consider assessing, on the basis of several factors, whether international law or EUR law is more appropriate. And it might, finally, insist on European public policy as a last barrier against an otherwise applicable UNSC Resolution. All in all, the technicality of conflict of laws would allow a more finetuned response to a difficult problem.

\footnotetext{
${ }^{62}$ See Knop et al., International Law, supra note
} 


\section{Conclusion}

One of the biggest shortcomings of discussions of global legal pluralism is that they, with rare exceptions (as named above), ignore conflict of laws as a discipline. This is a main reason for why these discussions have stalled. Global legal pluralism is widely accepted as a helpful description of law in the world, but because a more precise conceptualization and theorization is lacking, that description has little impact for further analysis. Proper discussions would instead assess, empirically, the legal ways in which actors and institutions respond, in a decentralized manner, to the situation of global legal pluralism. They would then, for a normative project, use these approaches to develop proper responses to global legal pluralism that can be legal in nature despite the absence of global institutions. Such steps would naturally lead to the conflict of laws, albeit in modernized form, as both the empirically and normatively most appropriate response to global legal pluralism. This chapter, in its brevity, could only sketch some of the elements of such an approach. May it motivate more such analyses. 